UDC 659.4.012:338.49

JEL D83, M31

DOI 10.26906/EiR.2021.1(80).2240

\title{
THE EFFECTIVENESS OF PRODUCT AND BRAND PROMOTION: THE ROLE OF MARKETING COMMUNICATIONS
}

\author{
Viktoriia Bondarenko*, PhD (Economics), Associate Professor \\ Oleksandr Khadartsev**, PhD (Economics), Associate Professor \\ Olesia Hryhorieva***, PhD (Economics), Associate Professor \\ National University «Yuri Kondratyuk Poltava Polytechnic»
}

\begin{abstract}
* ORCID 0000-0003-4625-0112
** ORCID 0000-0002-3520-4164

*** ORCID 0000-0001-7524-7161
\end{abstract}

\begin{abstract}
(C) Bondarenko V., 2021.
(C) Khadartsev O., 2021.

(C) Hryhorieva O., 2021.
\end{abstract}

Стаття отримана редакиією 07.03.2021 p.

The article received by the reduction 07.03.2021.

Introduction. Marketing is characterized with a variety of multifaceted tools: to identify patterns of potential consumers' behavior; to determine effective mechanisms for product promotion. In this point, the urgent problem is always to determine the most optimal models of marketing communications and the formation of marketing tools for managing these communications. Marketing communications is one of the key elements in the effectiveness ensuring of product promotion and interaction with consumers. Taking into account the current economic and social characteristics of the market environment, in this case, the leading role in the communication mechanisms functioning is given to the brand. At the same time, marketing communications is often given a secondary role or a separate application, which leads to underestimation of the role of marketing communications in strategy's formation of the enterprise market and product competitiveness; and consequently - to non-use of potential competitive advantages and to loss of prospective consumer segment.

Analysis of recent research sources and publications. Problems of marketing communications and their effective arrangement are studied in the works by many domestic and foreign scientists. In particular, it should be noted the publications by the following authors: Yu.V. Mironova, O.O. Kahliak and O.V. Pityk [1], A.F. Pavlenko, A.V. Voichak and T.A. Prymak [3], H.H. Pocheptsov [4], F. Kotler and J. Kaslione [6], Ye. Romat [12], J. Yang and A. Battocchio [14], H. Sadek, S. Elwy and M. Eldallal [17], et al. However, despite the significant achievements in this sphere, identifying the role of marketing communications for the enterprise requires further study, in particular in terms of communication impact and interaction between the category "brand" and customers-consumers of brand's products.

Purpose. The purpose of the article is to investigate the features and role of marketing communications in the activities of enterprises, to identify factors that increase their efficiency and performance.

Results. Effective use of marketing is impossible without the existence of an effective communication system. An acceptable pricing policy and well-chosen sales channels may not give the desired result without bringing the information to the consumer. That is why communication policy is one of the components of marketing [1]. Theoretical research has shown the growing importance of marketing communications. Along with this, among researchers there is no single point of view on the definition of the concept and components of the complex of marketing communications as a complex of promotion. Marketing communications should be understood as the process of transmitting information about the company and its products in order to influence the target audience and obtain counter-information about the reaction of these audiences to the impact of the company. The activity of companies in the field of communications can be considered successful only if it significantly achieves the goals and objectives. In the case of impact on the target audience, the main purpose of marketing communications is to change its attitudes or behavior, i.e., the transition from one state to another. Tasks, been set in accordance with the goal 
above, may relate to various aspects of the activity. Effective communication with consumers has become a key factor in the market promotion of any organization. Modern marketing requires much more than simply creation of a product, which meet customer's needs. Businesses need to communicate with their customers. At the same time, there should be nothing accidental in the content of communications. Therefore, the key to the success of the enterprise in the market is the ability to organize properly the interaction of many tools of marketing communications with the definition of the most effective and efficient means of communication in each case of economic activity of the enterprise [2].

Theoretical aspects of marketing communication in business are the subject of research by many authors. Marketing communications are information and psychological connections between market objects, which are established to ensure mutually beneficial relations and achieve the marketing goals of the communicator in the process of creating and distributing certain values. Marketing communication policy is a prospective course of action of the firm, aimed at ensuring interaction with all actors in the marketing system based on a well-grounded strategy of using a set of marketing communications, to meet the needs of consumers and make a profit [3]. Marketing communications are the basis for all areas of market activity, the purpose of which is to achieve success in the process of meeting the aggregate needs of society. They are used as an effective marketing tool, which includes the practice of bringing to consumers the information necessary for the enterprise, and are considered as a process of managing the movement of goods at all stages: at the time of product launch, before sale [4]. The objectives of an effective marketing communications policy are [3]:

- creating a prestigious image of the manufacturer and its products;

- informing potential consumers about goods, prices, application features, advantages over competitors' goods, etc.;

- offering new goods, services, ideas on behalf of the manufacturer;

- maintaining the popularity of goods that are already on the market;

- providing consumers or intermediaries with information on the conditions of stimulating the sale of goods;

- development of marketing communication measures that would persuade consumers to buy products from this manufacturer;

- providing feedback to the consumer to determine the attitude towards the manufacturer and his products.

The general program of marketing communication of the enterprise is a complex of advancement, and represents a combination of five basic means of advancement [5].

1. Advertising - a paid form of impersonal presentation and promotion of ideas, goods and services, which is ordered and funded by a particular sponsor. The main task of advertising is to encourage the purchase of this product by a particular consumer (buyer). Therefore, advertisers need to know whether advertising has managed to create, maintain, deepen the image of the company and its product or service, whether advertising has encouraged the product to buy it, whether it has created a circle of regular customers, and so on.

2. Personal sale - the presentation of goods to one or more potential customers, which is carried out in the process of direct communication and aims to sell and establish long-term relationships with customers. Personal selling is used in some cases much more often than other means of promoting goods and is more effective in the wholesale sale of goods.

3. Sales promotion - one-time incentives that encourage the purchase of certain goods or services. It is worth noting that the stimulation on the Ukrainian market began with simple tastings, which became very popular among consumers. The effectiveness of the sales promotion system is greatly enhanced when its tools are used in conjunction with other forms and elements of product promotion, such as advertising and personal selling.

4. Public relations - establishing relationships between the company and various contact audiences by creating a good reputation for the company, a positive corporate image, on the one hand, and eliminating or preventing unwanted rumors, gossip and actions - on the other. The main tools of public relations are contacts with the press, building a reputation, corporate communications, meetings of company representatives with consumers and consulting. Thus, public relations (PR) are a prerequisite and an important part (especially today) of marketing. According to some marketers, public relations is becoming a new, fifth element of marketing, complementing product, price, promotion, place and becoming a new "P”.

5. Event marketing - the use of various means of communication for direct communication with customers, designed to get a certain reaction. It involves the use of mail, telephone and other channels that 
allow you to reach a certain category of consumers or get an immediate response.

Although advertising effects have been the subject of research for decades, there is currently no clear approach to determining the advertising effect. There are economic and psychological components of advertising effects [6; 7]. Psychological advertising effects can be summarized using a multi-layered advertising effect - the attitude of consumers. Attitude - is any change in the consciousness and/or subconscious of the consumer, resulting in an economic advertising effect, i.e., consumer behavior in the form of buying the product. The formation of an appropriate attitude serves as a basis for future economic results, with a certain combination of situational factors.

Of course, every company aims to make a profit, so the economic advertising effect for everyone becomes the main thing, and the company, as a result of consumer behavior, expects an increase in sales in the first place. But (according to scientists who have studied the effects of advertising effects) it is almost impossible to identify the share of sales, which has increased due to the system of marketing communications of the enterprise. After all, there are many factors that increase the company's profits. Depending on the source of influence, there are three groups of the factors [8]:

- internal factors of the advertiser - compliance of advertising influence with the used marketing strategies of the enterprise and its strategic plans, as well as the capabilities of the enterprise;

- factors related to the target audience of advertising - psychological features of the perception of advertising, as motivation, previous experience, etc.;

- factors of the external marketing environment.

All marketing communication tools are closely related and have a common goal: to accelerate the promotion of goods in target markets; to encourage customers to take active action (purchase or repeat purchases, dissemination of feedback and recommendations). However, they help to achieve a common goal in different ways and play a different role in the implementation of marketing tasks [9]. Thus, marketing communications transform the market into a specific social category, and the key centralized phenomenon of which - is the brand.

The brand can be rightly considered as the embodiment of various "paradigms of values" promoted by the manufacturer and sought by the consumer: philosophical, cultural, psychological, sociological, marketing, economic. The brand is able to act as a motivator of consumption, "psychological" of brand - is identified with the effectiveness of marketing communication and consumer loyalty to the brand, and this is the conceptual basis of brand's success and profitability [10, p. 53-54]. Accordingly, in today's market environment, the brand is beginning to play a leading role of communicational "point of contact" between the supply and demand. Therefore, the organization of effective marketing communication should be based on determining the correct vector of translation of brand values. This, in turn, ensures the implementation of business goals of a particular business entity, as well as long-term fruitful interaction with customers or consumers [11, p. 121]. According to theoretical research and practical developments, such efficiency is achieved by following the model of "communication pyramid" - a hierarchical system of marketing communication goals, where each subsequent level is based on the previous one and represents a gradual achievement of higher and more complex communication goals [12]:

- brand awareness by the target consumer audience;

- expanding knowledge about the brand by target audiences;

- formation of psychological associations of the brand in the mind

- representatives of target audiences;

- brand identification and differentiation;

- formation of a positive brand image;

- communication to the target audiences of the mission, vision and essence of the brand;

- promotion of brand values;

- stimulating sales of branded products (corporate brand of the company);

- formation of brand loyalty;

- reminders about the brand to representatives of target audiences.

The reverse effect of the communicative influence of the brand on consumer behavior is a significant activation of the mechanisms of social comparison. Thus, a particular consumer, comparing himself with other individuals, gets the opportunity to assess their own abilities, attractiveness, personality traits, comparing past and current situational-factor environment. In the social plane, this leads to categorization the moral-aesthetic and psychological process of assigning the subject to a certain class, on the basis of perceptual standards, stereotypes of behavior, lifestyle, and so on. Studies show that the features of social 
comparison and categorization, although, allow to build more effective communication to ensure consumer loyalty to the brand, but the intensity of social comparison and categorization does not depend on the level of income [13]. Thus, effective marketing communication allows to eliminate a number of restrictive barriers to consumption and thus to carry out structural transformation of the market environment.

However, the design of effective marketing communications and the specification of forms and methods of their implementation depends on the initial segmentation of the client by economic and social nature: consumer preferences and expectations; level of well-being; fashion trends in society; moral qualities; desire for self-expression, etc. [14]. Therefore, long-term arrangement of "communication bridges" is possible with a clear establishment of such specific requirements - the customer's/client's avatar. In terms of communication, a customer's avatar is a reflection of the type of person who is really loyal to a certain brand (brands) - this is the "ideal customer". Modern market features show that the customer's avatar is a key element of marketing strategy, a specific reflection of the target audience and a comprehensive segment for research or obtaining data from the market [15]. Marketers note that an established customer avatar provides $80 \%$ success in promotion, as it allows to turn the average consumer into a "fanatic" of a particular brand; resources and efforts to identify the avatar can pay off in the plural.

In this sense, it is advisable to refer to the practical results of the market environment. According to the results of the number of studies from Online Market Intelligence about brand communications in the markets of post-Soviet countries [16], was revealed a stable correlation between:

- positioning and value proposition of the brand - on the one hand;

- socio-psychological type of behavior and motives for decision-making - on the other hand.

According to the results of such studies, 5 typical groups - customer avatars were identified [16], and also their propensity in terms of specific brands (Fig. 1).

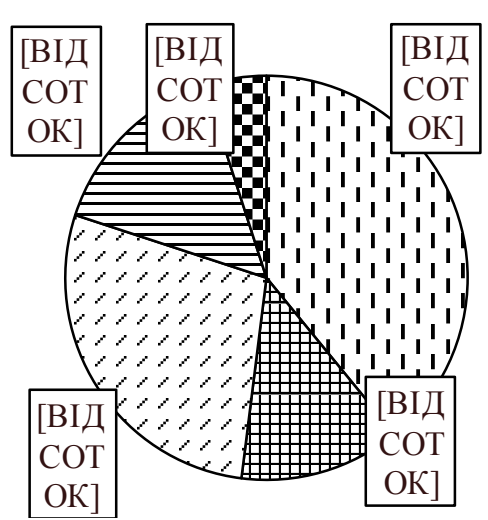

a) $A P P L E$

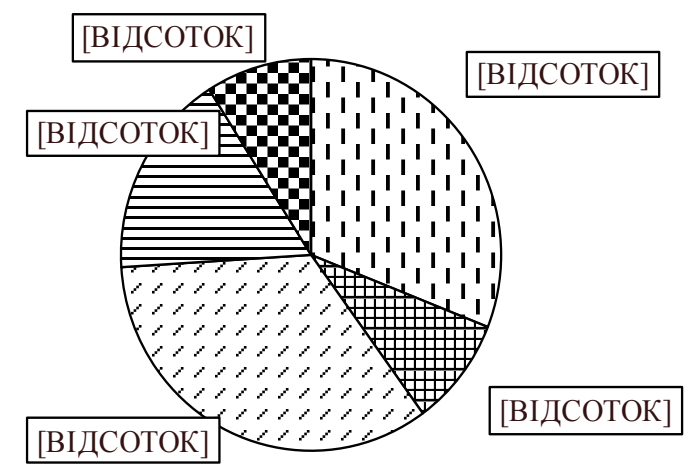

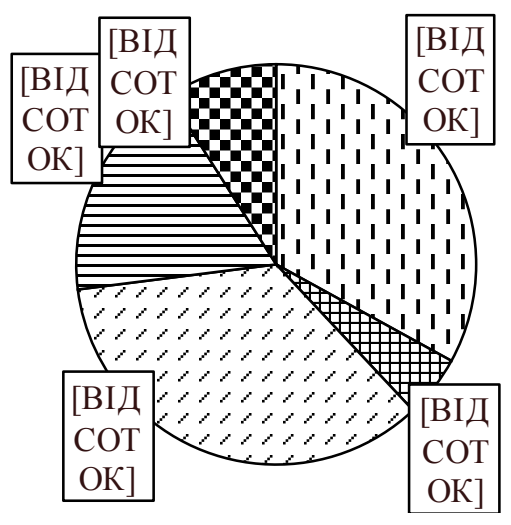

b) SAMSUNG

๑Shopaholic-esthete

由Consumer on show

๑ Moderate rationalist

$\boxminus$ Rationalist

QTraditionalist

\section{c) SONY}

*Source: [16]

Fig. 1. Customer's avatars in brands: Apple, Samsung, Sony*

1. "Shopaholic-esthete". This avatar is guided by feelings, not the mind, active and dynamic, likes to 
spend time away from home, easily changes residence, work. He has an active social position, wants to benefit society, and does not depend on advertising, but his consumer behavior depends on fashion trends. Such a customer is prone to impulsive shopping, shopping for him is a holiday, he likes to go to expensive stores, because the buying process itself is fun, the one does not plan expenses and buys more than really needs.

2. "Consumer on show". According to the description, the one is close to the previous avatar social, emotional, active and dynamic, but very dependent on advertising and has the image of a person who follows to the newest. Such a customer always listens to the opinion of friends, can buy a very fashionable thing, even if it is inconvenient, but never buys unfamiliar brands, even for the sake of saving.

3. "Moderate rationalist". The one is guided by the arguments of reason, pays great attention to value for money, is not ready to overpay for the brand. Does not consider as necessary to keep up with fashion, buys only what he really needs, plans and controls his expenses. Such a customer adheres to the strategy of buying different products of certain brands, been sure of their quality in practice.

4. "Rationalist". Such a client declares that he lives with his mind, not his feelings, carefully plans his budget, does not buy on credit, tries to avoid unforeseen expenses. He is reasonably frugal, goes to inexpensive stores, is willing to buy unfamiliar brands for the sake of saving and mostly does not trust advertising. This client is looking not so much for the cheapest, but for the best value-money options.

5. "Traditionalist". Such an avatar is the complete opposite to the "shopaholic-esthete" - the one lives with his mind, does not follow fashion, goes to cheap shops, buys goods, guided solely with savings, does not borrow money at all. This customer is quite conservative and passive, he based on the desire to save products in choosing products, so none of the advertised brands can become his favorite.

This dispensation fully reflects the results of leading brands of marketing communications and the positioning specificity. Effective promotion is formed under the affection of the decisive influence of the customers' avatar, which ensures the effectiveness of marketing communication. The meaning of the format and methodology of marketing communications is especially important for the sphere of fast-moving consumer goods, where the decision is usually made instantly, without long-term rationale, and directly at the point of sale. In particular, researchers note [17] the need for companies to pursue an active communication and content policy in social media to overcome the irrelevant content, which is generated by users of social networks (Table 1).

Table 1

The variables and their items, explanatory factor analysis (EFA), confirmatory factor analysis (CFA) and the average variance extracted (AVE) of each variable*

\begin{tabular}{|c|c|c|c|c|}
\hline Variables & Items & EFA & CFA & AVE \\
\hline \multirow{4}{*}{$\begin{array}{l}\text { Firm-created } \\
\text { social media }\end{array}$} & $\begin{array}{l}\text { I am satisfied with the company's social media } \\
\text { communications conducted via Facebook for this brand }\end{array}$ & 0.899 & 0.886 & \multirow{4}{*}{$73.331 \%$} \\
\hline & $\begin{array}{l}\text { The level of the company's social media communications } \\
\text { conducted via Facebook for this brand meets my expectations }\end{array}$ & 0.857 & 0.824 & \\
\hline & $\begin{array}{l}\text { The company's social media communications conducted via } \\
\text { Facebook for this brand are very attractive }\end{array}$ & 0.878 & 0.824 & \\
\hline & $\begin{array}{l}\text { The company's social media communications conducted via } \\
\text { Facebook for this brand perform well, when compared with } \\
\text { the social media communications of other companies }\end{array}$ & 0.787 & 0.715 & \\
\hline \multirow{4}{*}{$\begin{array}{l}\text { User-generated } \\
\text { social media }\end{array}$} & $\begin{array}{l}\text { I am satisfied with the content generated on Facebook by } \\
\text { other users about this brand }\end{array}$ & 0.826 & 0.748 & \multirow{4}{*}{$72.393 \%$} \\
\hline & $\begin{array}{l}\text { The level of the content generated on Facebook by other } \\
\text { users about this brand meets my expectations }\end{array}$ & 0.867 & 0.863 & \\
\hline & $\begin{array}{l}\text { The content generated on Facebook by other users about this } \\
\text { brand is very attractive }\end{array}$ & 0.839 & 0.862 & \\
\hline & $\begin{array}{l}\text { The content generated on Facebook by other users about this } \\
\text { brand performs well, when compared with other brands }\end{array}$ & 0.870 & 0.801 & \\
\hline
\end{tabular}

*Source: [17]

This moderation allows to ensure the competitiveness of the brand at a high level. In the information society, the Internet becomes an environment for users to stay and interact in the form of community formations, where their own information space is formed, which also affects consumer behavior [18]. 
Researchers note that the model of the communication process in Internet changes - from the traditional "one-to-many communication model" to "many-to-many communication model". This leads to changes in the object of marketing communications on the Internet: from a specific consumer to a whole group - a virtual community of consumers who interact with each other within each community.

Conclusion. In modern conditions, companies must actively implement marketing communications, that will increase an influence on existing and potential consumers, enhance competitive positions in existing markets, increase access to new markets and raise up profitability. The ability of strategically organization of the interaction of many marketing communications tools with the definition of the most effective means of communication in each case of economic activity of the enterprise - this is the key to the market success. Effective marketing communications contribute to the growth of the company's image and competitiveness, consolidation of the brand or organization image. Customer's avatars and communication channels, for achievement positive marketing effect and dominance, should be used in combination, depending on the product factor's peculiarities and the situation in a particular market environment.

\section{REFERENCES:}

1. Mironova, Yu.V., Kahliak, O.O. \& Pityk, O.V. (2016). Naukovo-teoretychni osnovy doslidzhennia marketynhovykh komunikatsiinykh protsesiv na pidpryiemstvi [Scientific and theoretical bases of research of marketing communication processes at the enterprise]. Visnyk Khmelnytskoho Natsionalnoho Universytetu. Ekonomichni nauky, 1, pp. 207-214 (in Ukrainian).

2. Zozulov, O.V. \& Poltorak, O.V. (2014). Zastosuvannia kraud-tekhnolohii v marketynhovii diyalnosti pidpryiemstv [Application of crowd-technology in marketing activities of enterprises]. Ekonomichnyi Visnyk NTUU “KPI”, 11, pp. $422-429$ (in Ukrainian).

3. Pavlenko, A.F., Voichak, A.V. \& Prymak, T.A. (2005). Marketynhovi komunikatsii: suchasna teoriia i praktyka [Marketing communications: modern theory and practice]. Kyiv: KNEU, 408 p. (in Ukrainian).

4. Pocheptsov, H.H. (1999). Teoriia komunikatsii [Theory of communication]. Kyiv: "Kyivskyi universytet”, 308 p. (in Ukrainian).

5. Dibrova, T.H. (2009). Marketynhova polityka komunikatsii: stratehii, vitchyzniana praktyka: navchalnyi posibnyk [Marketing policy of communications: strategies, domestic practice: tutorial]. Kyiv: Vydavnychyi dim "Profesional", 320 p. (in Ukrainian).

6. Kotler, F. \& Kaslione, J. (2009). Khaotyka: upravlinnia ta marketynh v epokhu turbulentnosti [Chaotics: management and marketing in the era of turbulence]. Kyiv: Khimdzhest, PLASKE. 208 p. (in Ukrainian).

7. Yudina, N.V. (2011). Sytuatyvnyi pidkhid do upravlinnia reklamnoiu diialnistiu [Situational approach to advertising management]. Visnyk Volynskoho Instytutu Ekonomiky ta Menedzhmentu, iss. 1. (in Ukrainian). Available at: http://www.nbuv.gov.ua/portal/Soc_Gum/Vviem/2011_1/30.pdf

8. Kuzyk, O.V. (2014). Stratehichne upravlinnia marketynhovymy komunikatsiiamy na suchasnykh pidpryiemstvakh [Strategic management of marketing communications in modern enterprises]. Stratehiia ekonomichnoho rozvytku Ukrainy, 34, pp. 130-135 (in Ukrainian).

9. Voinarenko, S.M. (2011). Komunikatyvna polityka pidpryiemstv v suchasnykh umovakh [Communicative policy of enterprises in modern conditions]. Visnyk Khmelnytskoho Natsionalnoho Universytetu, 6, vol. 2, pp. 51-54 (in Ukrainian).

10. Poplavskyi, M. (2018). Brend-komunikatsiia yak sotsialne yavyshche [Brand communication as a social phenomenon]. Ukrainskyi informatsiinyi prostir (naukovyi zhurnal), 2, pp. 47-58. (in Ukrainian).

11. Lytvynova, V.V. \& Liashchenko, A.V. (2018). Komunikatsiini stratehii u prosuvanni brendu [Communication strategies in brand promotion] / Zbiur artykuluw naukowych $z$ Konferencji Miedzynarodowej Naukowo-Praktycznej "SCIENCE, RESEARCH, DEVELOPMENT \#5”, Warszawa, pp. 117-122 (in Ukrainian).

12. Romat, Ye. (2016). Systema brend-marketynhovykh komunikatsii [Brand-marketing communication system]. Tovary i rynky, 1, pp. 16-25 (in Ukrainian).

13. Homolska, L.P. (2017). Sotsialne porivniannia ta katehoryzatsiia yak sotsialno-psykholohichni mekhanizmy brend-komunikatsii [Social comparison and categorization as socio-psychological mechanisms of brand communication]. Naukovyi Visnyk Khersonskoho Derzhavnoho Universytetu. Seriia: Psykholohichni nauky, 3 (2), pp. 160-164 (in Ukrainian).

14. Yang, J., \& Battocchio, A.F. (2020). Effects of transparent brand communication on perceived brand authenticity and consumer responses. Journal of Product \& Brand Management. 
15. DeVries, H. (2019). What Is An Ideal Customer Avatar? Forbes, 25 Sep. Retrieved from: https://www.forbes.com/sites/henrydevries/what-is-an-ideal-customer-avatar/?sh=6554a5957327

16. Samsung lyubyat "umerennye ratsionalisty" - Eksperty issledovali psykhotipy potrebiteley [Samsung is loved by "moderate rationalists" - Experts have studied the psychotypes of consumers]. SOSTAV - proekt brendingovogo agentstva Depot WPF (in Russian). Retrieved from: https://www.sostav.ru/news/2012/12/05/samsung_racionalist

17. Sadek, H., Elwy, S. \& Eldallal, M. (2018). The impact of social media brand communication on consumer-based brand equity dimensions through Facebook in fast moving consumer goods. Journal of Business and Retail Management Research, 12(2), pp. 107-120.

18. Shklyayeva, H.O. (2014). Interaktyvni marketynhovi komunikatsii u menedzhmenti pidpryiemstva [Interactive marketing communications in enterprise management]. Ekonomichnyi nobelivskyi visnyk, 1(7), pp. 509-515 (in Ukrainian).

УДК 659.4.012:338.49

JEL D83, M31

Бондаренко Вікторія Михайлівна, кандидат економічних наук, доцент. Хадарцев Олександр Валентинович, кандидат економічних наук, доцент. Григор'сва Олеся Володимирівна, кандидат економічних наук, доцент. Національний університет «Полтавська політехніка імені Юрія Кондратюка». Ефективність просування товарів та брендів: роль маркетингових комунікацій. Розглянуто особливості й роль маркетингових комунікацій, зокрема в аспекті впливу та взаємодії між категоріями «бренд» та «клієнт-споживач продуктів бренду». Досліджено специфіку діяльності компаній у сфері комунікацій, визначено ключові чинники, що забезпечують спроможність віднайти ефективні засоби й інструменти маркетингових комунікацій. Розглянуто завдання та елементи формування маркетингової політики комунікацій. Дано характеристику основних засобів комплексу просування як програми маркетингової комунікації підприємства. Розглянуто складові рекламних ефектів як точок комунікативної взаємодії між споживачем і товаром. Виокремлено значущість бренду як комплексної інтеграції ціннісних пропозицій виробника і споживчих очікувань клієнта. На підставі аналізу сучасних особливостей ринку обгрунтовано, що аватар клієнта є основою формування маркетингових комунікацій як відображення цільового сегмента. Досліджено розподіл прихильності до певних брендів у розрізі відповідних аватарів клієнтів. Охарактеризовано вплив соціальних медіа на формування ефективності комунікаційних каналів, зокрема для сектора товарів повсякденного вжитку. За результатами проведених досліджень, зроблено відповідні висновки щодо подальшого вдосконалення маркетингових комунікацій на підприємстві з метою зростання іміджу компанії та її конкурентоспроможності, консолідації іміджу бренду або організації.

Ключові слова: маркетингові комунікації, бренд, аватар клієнта, просування, канали комунікацій.

UDC 659.4.012:338.49

JEL D83, M31

Bondarenko Viktoriia, PhD (Economics), Associate Professor. Khadartsev Oleksandr, PhD (Economics), Associate Professor. Hryhorieva Olesia, PhD (Economics), Associate Professor. National University "Yuri Kondratyuk Poltava Polytechnic". The Effectiveness of Product and Brand Promotion: the Role of Marketing Communications. In the article features and role of marketing communications, particularly in the aspect of influence and interaction between categories "brand", clients-consumers of brand's products are considered. The specifics of companies' activities in the field of communications are studied. There are considered tasks and elements of formation of marketing communications policy in this paper. The characteristic of the basic means of a complex of advancement, as a program of enterprises' marketing communication are given. It is substantiated that the client's avatar is the basis for the formation of marketing communications. There are made appropriate conclusions, regarding the further improvement of marketing communications at the enterprise.

Keywords: marketing communications, brand, customer avatar, promotion, communication channels. 